\title{
The Crown and Statutes
}

\author{
P. Fackson*
}

In Tamlin v. Hannaford ${ }^{1}$ Denning LJ, as he then was, said:

"It is, of course, a settled rule that the Crown is not bound by a statute unless there can be gathered from it an intention that the Crown should be bound."

As Master of the Rolls he again referred to the rule when considering whether the Crown needed to obtain planning permission to change the use of certain land:

"Looking at the whole of the Town and Country Planning Act, 1947, I am satisfied that the Crown does not need to get planning permission in respect of its own interest in Crown lands. The reason why it is exempt is, not by virtue of any provision in the Act itself, but by reason of the general principle that the Crown is not bound by an Act unless it is expressly or impliedly included."2

The existence of the rule may well be settled but its scope remains open to argument, as evidenced by the recent decision of the House of Lords on appeal from Scotland: Lord Advocate v. Dumbarton D.C. ${ }^{3}$ Nor is it always clear whether a particular body is entitled to claim to be part of "the Crown" for the purpose of immunity from legislation or in order to be able to claim the benefit of statutory provisions such as section 21 of the Crown Proceedings Act 1947: British Medical Association v. Greater Glasgow Health Board. ${ }^{4}$

Formulations of a rule reflecting the privileged position of the Crown date back to the mid-fifteenth century. ${ }^{5}$ In Willion v. Berkley, ${ }^{6}$ a case where the Crown was

* Professor of Law, University of Reading.

1. [1950] 1 K.B. $18,22$.

2. [1963] 2 Q.B. $317,325$.

3. [1989] 3 W.L.R. 1346.

4. [1989] A.C. 1211.

5. See H. Street, Governmental Liability (1953), pp.143-144. In Lord Advocate v. Dumbarton D.C. [1989] 3 W.L.R. 1346, 1351 Lord Keith of Kinkel cites the formulation Roy n'est lie per ascun statute, si il ne soit expressement nosme (fenk. Cent. 307) which is adopted in Broom, Legal Maxims, p. 38. Jenkins, a contemporary of Coke, wrote his Centuries "amidst the sound of drums and trumpets . . broken with old age and confinement in prison": J.W. Wallace, The Reporters 4th ed. (1882), p.70.

6. Willion v. Berkley (1561) Plowden 223. 
held to be bound by the statute De Donis Conditionalibus, counsel on the losing side explained the rule on the ground that the King, when assenting to an Act, does not intend to prejudice himself or to bar himself of his liberty and privilege but he assents that it shall be a law among his subjects. That, as Wrottesley J observed in Attorney General v. Hancock, " "would, perhaps, nowadays be regarded as rather an overstatement of the position of the Crown with regard to Acts of Parliament." It was not necessarily so obviously an over statement at a time when the Crown was not in any event liable to be sued in its own courts ${ }^{8}$ and the range of legislation was far more restricted than in the last hundred years. In more modern terminology the rule can best be described as reflecting a presumed intention of Parliament or as "only an instance of a mere [sic] general rule. The doctrine that the words of an instrument shall be taken most strictly against the party employing them does not apply to the Crozm. Such a grant is construed most strictly against the grantee and most beneficially for the Crown ..." Thus the rule should be regarded as one of construction rather than a prerogative of the Crown, ${ }^{10}$ a view endorsed by the House of Lords in Lord Advocate v. Dumbarton D.C. ${ }^{11}$ In the following pages it is intended to discuss whether the rule or presumption applies to all statutes; the meaning for the purpose of the rule of "Crown"; the right of the Crown to take the benefit of an Act of Parliament although not named therein ${ }^{12}$ and finally to criticise the current position.

\section{Statutes within the rule of construction}

Dicta in old cases and statements in writers such as Blackstone and Chitty suggested that the rule of construction in favour of the Crown applied to statutes which would divest or abridge the king of "his rights or interests"13 or "his prerogatives, his interests or his remedies." 14 In a further category of statutes there was a presumption that the king was bound even by implication, namely statutes "expressly made for the preservation of public rights and the suppression of public

\section{7. [1940] 1 K.B. 427, 431.}

8. See O. Hood Phillips, Constitutional and Administrative Law 7th ed. (1987), p.702.

9. H.V. Evatt, The Royal Prerogative (1987), p.42. For a discussion of the privileged position of the Crown in relation to deeds, see Lonsdale (Earl of) v. Attorney-General [1981] 1 W.L.R. 887. The reversal of the normal presumption was referred to - but in the absence of an ambiguity its applicability did not have to be decided - at first instance in Inglewood Investment v. Forestry Commission [1988] 1 W.L.R. 959; affirmed [1988] 1 W.L.R. 1278.

10. P.W. Hogg, Liability of the Crown (1971), pp.166-167. The Crown Proceedings Act 1947, s.40(2)(f) cautiously refers to "any rules of evidence or any presumption relating to the extent to which the Crown is bound by any Act of Parliament."

11. [1989] 3 W. L.R. 1346, 1360 per Lord Keith of Kinkel, approving a dictum of Diplock LJ in British Broadcasting Corporation v. Fohns [1965] Ch. 32, 78-79, and explaining dicta in Madras Electric Supply Corporation Lid. v. Boarland [1955] A.C. 667. See Roberts v. Ahern (1904) 1 C.L.R. 406, 417 per Griffith CJ; Minister for Works (W.A.) v. Gulson (1944) 69 C.L.R. 338, 347 per Latham CJ; Commonwealth v. Bogle (1953) 89 C.L.R. 229, 259 per Fullager J: "[A] pure question of construction."

12. Blackstone, Comm., i,262; Craies on Statute Law 7th ed. (1971), p.438.

13. Blackstone, loc. cit.

14. Chitty, Prerogatives of the Crown (1820), p.383. 
wrongs [provided that they did] not interfere with the established rights of the Crown." 15 Chitty states that to the general rule

"there is a most important exception, namely, that the King is impliedly bound by statutes passed for the public good; the relief of the poor; the general advancement of learning, religion and justice; or to prevent fraud, injury or wrong ... And the Crown, though not named, is bound by the general words of statutes which tend to perform the will of a founder or donor."16

The scope of the rule favouring the Crown in modern law fell to be considered by the House of Lords in Lord Advocate v. Dumbarton D.C. ${ }^{17}$ since, although an appeal from Scotland, their Lordships held that the law of Scotland on the question must agree with the law of England - which had therefore to be determined in the light of the modern cases. The Ministry of Defence had decided to erect an improved security fence around the submarine base at Faslane, Dumbartonshire. The execution of the work - which was undertaken by a firm of contractors, Tarmac Construction Ltd. - involved erecting various temporary buildings on part of a road adjoining the base. Strathclyde Regional Council claimed that as roads authority for the area it was entitled under the Roads (Scotland) Act 1984 to call for the removal of the various structures connected with the fencing work. The Dumbarton District Council, as local planning authority, served on the Property Services Agency, through which the Ministry of Defence was acting, an enforcement notice under section 84 of the Town and Country Planning (Scotland) Act 1972 requiring the restoration of the road to its former unrestricted use as a public highway. The Ministry of Defence claimed that neither statute bound the Crown and the Lord Advocate sought declarators to that effect in the Court of Session. At first instance Lord Cullen found for the Crown. The First Division, however, held that the relevant legislation did bind the Crown. From that decision the Lord Advocate appealed to the House of Lords. (By the time the appeal was heard the construction work had been completed so that, as Lord Keith pointed out, ${ }^{18}$ the question in a sense had become academic. Nonetheless it was appropriate that the House should decide the issue because of its general importance and the matter of costs remained a live one. $)^{19}$

In allowing the Crown's appeal Lord Keith recognised that prior to the union of 1707 Scots law knew no presumption that the Crown was not bound by an Act of

15. Blackstone, supra n. 12.

16. Ibid., citing the Magdalen College Case (1615) 11 Co.Rep.66b. See too Craies, p.439 et seq.; Broom, Legal Maxims, pp.39-40.

17. [1989] 3 W.L.R. 1346 ,

18. [1989] 3 W.L.R. 1346, 1351.

19. Similarly British Medical Association v. Greater Glasgow Health Board [1989] A.C. 1211. For an even more striking example of the role of costs in giving jurisdiction to appellate courts, see Mahon v. Air New Zealand [1984] A.C. 808. 
Parliament. ${ }^{20} \mathrm{He}$ traced the adoption of the English doctrine through the Court of Exchequer in a series of cases dealing with taxation - and then referred to two cases dealing with the powers of local authorities to regulate building operations. In the second of these cases the Lord President Dunedin said:

"While I do not doubt that there are certain provisions by which the Crown never would be bound unless that were clearly expressed - such, for instance, as the provisions of a taxing statute, or certain enactments with penal clauses adjected, as, for example, certain provisions of the Motor Car Act, and so on - yet, when you come to a set of provisions in a statute having for its object the benefit of the public generally, there is not an antecedent unlikelihood that the Crown will consent to be bound, and this, I think, would be so in the case of regulations which are meant to apply to all the land in a city, and where the Crown's property is not property held jure coronae, but has been acquired from a subject-superior for the use of one of the public departments." 21

There was, Lord Keith continued, no rational ground on which a different approach to the construction of a statute for the purpose of ascertaining whether it bound the Crown should be adopted in Scotland and England. Therefore it was appropriate to consider the modern English cases.

"The law has developed to a point where it is not helpful to refer to writings of greater or less antiquity which discuss the prerogatives of the Crown." ${ }^{\prime 22}$

Lord Keith examined the English cases since Gorton Local Board v. Prison Commissioner ${ }^{23}$ and concluded that they established that the Crown is not bound by a statute unless by express words or necessary implication. ${ }^{24}$ Nor will the Courts easily find that a statute applies to the Crown by implication. In Province of Bombay v. Municipal Corporation of the City of Bombay ${ }^{25}$ Lord Du Parcq, delivering the opinion of the Privy Council, suggested that a necessary implication that the Crown was to be bound would arise only where it is apparent from the terms of a statute that its beneficent purpose would otherwise be wholly

20. See further J.D.B. Mitchell, "The Royal Prerogative in Modern Scots Law", [1957] P.L. 304; J.D. B. Mitchell, Constitutional Law 2nd ed. (1968), p.183.

21. Magistrates of Edinburgh v. Lord Advocate 1912 S.C. 1985, 1090-1, citing with approval a similar dictum of Lord Kyllachy in Somerville v. Lord Advocate (1893) 20 R.1050, 1064-5.

22. [1989] 3 W.L.R. $1346,1354$.

23.[1904] 2 K.B. 164, 165n. (Gorton had been decided in 1887 but reported as a note to Cooper $v$. Hawkins).

24. Hornsey U.D.C. v. Hennell [1902] 2 K.B. 73, 80 per Lord Alverstone CJ; Attorney-General v. Hancock [1940] 1 K.B. 427, 439 per Wrottesley J; Attomey-General v. Randall [1944] 1 K.B. 709, 712 per Morton J; Ministry of Agriculture, Fisheries and Food v. Jenkins [1963] 2Q.B. 317, 325 per Denning LJ; British Broadcasting Corporation v. Johns [1965] Ch. 32, 78-79 per Diplock LJ.

25. [1947] A.C. 58. 
frustrated. Nor would an express saving clause exempting the Crown from particular provisions of an Act be sufficient to rebut the application of the normal rule of construction to other sections of the Act. Such saving provisions were to be regarded as being inserted ex abundanti cautela ${ }^{26}$ Lord Du Parcq also indicated that he did not regard the dictum of Lord President Dunedin ${ }^{27}$ as representing English law on Crown immunity.

Counsel for the local authorities attempted to limit the scope of the rule of construction by arguing that it only applied to cases where the Crown's lawful freedom of action would be constrained. Thus if it were accepted that the Crown had no right to erect structures on a highway any legislation relating to obstructions on highways should be interpreted in its application to the Crown without resort to any presumption of non-application. Lord Keith emphasised the practical difficulties of such an approach. The Crown in some circumstances might be entitled, like any private owner of premises, to obstruct the highway. ${ }^{28} \mathrm{It}$ would be absurd to suggest that in such circumstances a statute did not bind the Crown but when the Crown was acting without any right the statute did bind:

"It is preferable, in my view, to stick to the simple rule that the Crown is not bound by any statutory provision unless there can somehow be gathered from the terms of the relevant Act an intention to that effect. The Crown can be bound only by express words or necessary implication. The modern authorities do not, in my opinion, require that any gloss should be placed upon that formulation of the principle. However, as the very nature of these appeals demonstrates, it is most desirable that Acts of Parliament should always state explicitly whether or not the Crown is intended to be bound by any, and if so what, of their provisions." 29

Lord Keith then considered the provisions of the relevant legislation and concluded that neither Act bound the Crown expressly or by necessary implication.

Of the alleged exceptions to the general presumption in favour of the Crown which depend on the authority of Coke's report of the Magdalen College Case ${ }^{30}$ that of statutes passed for the public good has been examined in a number of modern cases and found wanting. In Territorial Auxiliary Forces Association of the County of London v. Nichols ${ }^{31}$ the Court of Appeal held that the Rent Acts did not bind the Crown. Scott LJ said, in reference to the argument that statutes passed for the

26. [1947] A.C. 58, 65. See also Hornsey U.D.C. v. Hennell [1902] 2 K.B. 73, 80, per Lord Alverstone CJ.

27. Supra n.21

28. The Crown did not in these proceedings rely on any prerogative right for the defence of the realm: [1989] 2 W.L.R. 1346, 1362.

29. [1989] 3 W.L.R. 1346, 1366.

30. (1615) 11 Co.Rep.66b; supra p.47; Craies, supra n.12, pp.439-444.

31. [1949] 1 K.B. 35. 
public good were to bind the Crown:

"Possibly the words had a meaning narrower than would attach to them today. It is difficult to suppose at the present day that any public statute is not in theory at least directed to the welfare of the public ... If the ancient rule ever had in fact the wide meaning claimed for it we can only conclude that it has been 'eaten away' by exceptions." 32

Similarly in Province of Bombay v. Municipal Corporation of the City of Bombay ${ }^{33}$ Lord Du Parcq expressed the view that the contention that statutes passed for the public good impliedly bind the Crown "cannot now be regarded as sound except in a strictly limited sense". ${ }^{34}$ In that case the Privy Council held that the Crown could refuse to allow the city authority to lay drains through Crown property despite a provision in the City of Bombay Municipal Act 1882 which gave the authority power to lay drains through or under "any street . . . and into through or under any land whatsoever within the city." In Department of Transport v. Egoroff ${ }^{55}$ the Court of Appeal refused to hold that the Housing Act 1961, sections 32 and 33, which implied certain obligations into leases, applied to leases granted by the Crown. Counsel conceded that the Act did not apply to the Crown expressly or by necessary implication. He argued, however, that it fell within the Magdalen College Case as a statute made to suppress a wrong. In rejecting that argument Parker LJ said that the classification of statutes in the Magdalen College Case was too wide to be of general assistance and had been wholly disposed of as a reliable guide by the Province of Bombay case.

Coke's dicta in the Magdalen College Case have been relied on in a number of old cases in which the Crown has been held to be bound by statute ${ }^{36}$ but it is difficult to believe that at the present time the fact that a statute fell within one of the categories he enumerated would be more than an element to be considered in construing the true meaning of the Act.

\section{The meaning of "the Crown"}

Once it had been held that a statute does not bind the Crown, "This question then becomes important - who and what are covered by the shield of the Crown?" 37 The meaning of the term "the Crown" may arise in various contexts,

\section{At p.45.}

33. [1947] A.C. 58.

34. At pp.62-63; cited, Lord Advocate v. Dumbarton D.C. [1989] 3 W.L.R. 1346, 1356.

35. The Times, 5 May, 1986; [1986] 1 E.G.L.R. 89; [1986] 18 H.L.R. 326.

36. Craies, supra n.12, pp.439-444. Craies comments on these cases (at p.443): "They are scarcely sufficient in number or variety to justify the very general adoption of the propositions propounded by Coke in the Magdalen College Case with regard to the kind of statutes by which the Crown is bound without being named."

37. W. Harrison Moore, "Liability for Acts of Public Servants", (1907) 23 L.Q.R. 12, 16. 
whether immunity from statutory provisions, immunity from judicial proceedings,$^{38}$ the application of provisions of the Crown Proceedings Act $1947,{ }^{39}$ or in situations where the divisibility of the Crown is an issue ${ }^{40}$ (which in federations such as Australia may well be involved in disputes over the scope of "Crown" immunity from legislation). ${ }^{41}$

At one extreme there can be little doubt that "the Crown" in the context of immunity from a statute includes the ministers of the Crown, the departments of state and the civil servants employed in those departments. ${ }^{42}$ In Gorton Local Board v. Prison Commissioner ${ }^{43}$ the Divisional Court, having held that the Public Health Acts did not bind the Crown, concluded without further ado that they did not apply to land on which the Prison Commissioners wished to erect houses for prison warders. The land in the words of Day J was "state property ... provided by the Crown for the purposes of the Crown ... occupied by servants of the Crown." Similarly the right of a local authority under the Public Health Act 1875, section 150, to recover from adjoining landowners the cost of paving a street was not enforceable against the Commanding Officer of premises used for the purposes of the 1st Volunteer Battalion (Duke of Cambridge's Own) Middlesex Regiment: Hornsey U.D.C. v. Hennell. ${ }^{44}$ In Attorney-General v. Hancock ${ }^{45}$ Wrottesley J held that the Courts (Emergency Powers) Act 1939 which forbade the bringing of actions to enforce judgments without the leave of the Court did not bind the Crown. The action in question related to a debt due to the Crown (arrears of income tax) and hence clearly, if the Act did not bind the Crown, could be brought without leave. Similarly in Attorney-General v. Randall, ${ }^{46}$ once the Court of Appeal had held that the Debtors Act 1869 did not bind the Crown, there could be no doubt that H.M. Customs and Excise could claim the advantage of that immunity to arrest the debtor, contrary to the terms of the Act. Again in Ministry of Agriculture, Fisheries and Food v. Fenkins ${ }^{47}$ the validity of a notice given to a tenant under the Agricultural Holdings Act 1948 depended on whether the landlord required the land for non-agricultural use for which planning permission was not required. The Court of Appeal held that the relevant planning legislation (the Town and Country Planning Act 1947) did not bind the Crown. The landlord as Minister of the Crown clearly fell within that Crown immunity. The shield covers not merely ministers and departments but any servant of the Crown: for

38. Mellenger v. New Brunswick Development Corporation [1971] I W.L.R. 604.

39. British Medical Association v. Greater Glasgow Health Board [1989] A.C. 1211.

$40 . R$. v. Secretary of State for Foreign and Commonwealth Affairs, ex parte Indian Association of Alberta [1982] Q.B. 892.

41. E.g., Minister for Works (W.A.) v. Gulson (1944) 69 C.L.R. 338; Commonwealth of Australia v. Bogle (1953) 89 C.L.R. 229; P.W. Hogg, Liability of the Crozon (1971) 188 et seq.

42. Cf. Town Investments v. Department of the Environment [1978] A.C. 359.

43. [1904] 2 K.B. $165 n$.

44. [1902] 2 K.B. 73.

45. [1940] 1 K.B. 427.

46. [1944] 1 K.B. 709.

47. [1963] 2 Q.B. 317. 
example a civilian driver employed by the Secretary of State for War was not liable to prosecution for exceeding the speed limit once it had been established that the statute did not bind the Crown: Cooper v. Hawkins, ${ }^{48}$

Difficult questions may, however, arise, for example, where duties are undertaken by independent or semi-independent bodies, whether incorporated or not, or by independent contractors. While each case must be decided on its facts some general principles can be drawn from the cases. First, in determining whether a person or body is "covered by the shield of the Crown" great weight is to be attached to the degree of control which the Crown through its ministers can exercise over the performance of the relevant duties. ${ }^{49}$ Secondly, immunity is likely to extend to those in consimili casu with Crown servants, discharging duties of a public nature connected with the Crown, for example the administration of justice. ${ }^{50}$ The dividing line between servants of the Crown and those in consimili casu may be fine and it is of no matter whether, for example, a volunteer regiment and its officers are exempt from a Public Health Act because they are Crown servants or in consimili casu therewith. Thirdly, as Denning LJ pointed out in Tamlin v. Hannaford, ${ }^{51}$ bodies carrying out commercial activities are unlikely to be regarded as part of the Crown: thus the Rent Acts were held in Tamlin to bind the British Transport Commission although they had earlier been held not to bind the Territorial Forces Association..$^{52}$ While, however, it may be relatively easy to distinguish commercial activities from those traditionally undertaken by the state, there is room for argument about the status of public bodies undertaking activities which formerly did not fall within the sphere of the Crown Service, for example in the field of broadcasting or health. In British Broadcasting Corporation v. fohns ${ }^{53}$ the Court of Appeal recognised that the scope of Crown services and activities could vary from time to time. There was no inherent reason why broadcasting should not be a Crown activity and broadcasting bodies part of the Crown. But the B.B.C. had been so clearly and deliberately created as an independent body that it could not claim the benefit of Crown immunity from taxing statutes. The Court contrasted broadcasting with the provision of health services where the legislative framework and degree of ministerial control made it appropriate to regard the activities of the National Health Service as a service of the Crown: Pfizer Corporation v. Ministry of Health. ${ }^{54}$ It does not, however, necessarily follow that a body providing Crown services or occupying land for Crown services is part of the Crown ${ }^{55}$ so that it can claim immunity from legislation or the benefit of section 21

48. [1904] 2 K.B. 164.

49. Bank Voor Handel en Scheepvaart N.V. v. Administrator of Hungarian Property [1954] A.C. 584.

50. Mersey Docks and Harbour Board v. Cameron (1865) 11 H.L.C. 443; Coomber v. Berkshire fustices (1893) 9 App.Cas 61.

51. [1950] 1 K.B. 18.

52. Territorial Auxiliary Forces Association of the County of London v. Nichols [1949] 1 K.B. 35.

53. $[1965]$ Ch. 62

54. [1964] Ch. 614 .

55. Nottingham Area No. I Hospiral Management Committee v. Owen [1958] I Q.B. 50. 
of the Crown Proceedings Act 1947 which prevents the granting of injunctions "in any proceedings against the Crown." In British Medical Association v. Greater Glasgow Health Board ${ }^{56}$ the House of Lords held that the health board was not entitled to immunity from interdict proceedings by virtue of that section because such proceedings were not proceedings against the Crown. The relevant legislation creating the predecessors of health boards had made them liable to be sued in their own names. That legislation ante-dated the Crown Proceedings Act 1947 which was an Act intended to make it easier rather than more difficult to sue the Crown. In the view of Lord Jauncey, who delivered the only speech, there was nothing in section 21 to show that it was intended to take away existing rights. Lord Jauncey found support also in section 17(3) which he thought showed that Parliament had in mind government departments and not bodies such as those running the National Health Service.

Against this background it is interesting to speculate whether in Lord Advocate v. Dumbarton D.C. ${ }^{57}$ Tarmac Construction, the independent company which carried out the work, could have relied on Crown immunity had the issue been explicitly raised as, unfortunately, it was not before the House of Lords. No doubt because the matter had by the time of the appeal become academic it was not thought worthwhile to pursue a topic subsidiary to the main issue of the position of the Crown. Some support for the view that Tarmac Construction could have claimed Crown immunity is found in Campbell A.G. (Arcam) Ltd. v. Worcestershire C.C. ${ }^{58}$ Land had been requisitioned by the War Office during the Second World War. It was then occupied by Shell-Mex in order to provide petrol supplies for the Army. In the Court of Appeal only Ungoed Thomas J considered the question and he concluded that the company was acting as agent of the Crown and hence entitled to the immunity from the Restriction of Ribbon Development Act 1935 which, it was agreed, was possessed by the War Office. It might be arguable that it is easier to establish a right to shelter behind the shield of Crown immunity when carrying out work on land occupied by the Crown than on facts such as in the Dumbarton D.C. case.

The problem has arisen in two Australian cases. In Roberts v. Ahern ${ }^{59}$ the High Court held that the Police Offences Act 1890, section 5 of which made it an offence to empty cesspits or cart nightsoil without a licence, did not bind the Crown. It then went on to hold that an employee of an independent contractor employed by the Crown to remove nightsoil from Crown premises could not be prosecuted for not having obtained the necessary licence. In Commonwealth of Australia v. Bogle ${ }^{60}$ however, Roberts v. Ahern was regarded as "an extreme application" of the law to the facts. In Bogle the running of hostels for immigrants had been entrusted 
by the government to a company of which all the incorporators were civil servants. The High Court held that the company could not rely on Crown immunity to claim exemption from the Prices Regulation Act 1948-1951 (Vict.). It was "simply a company formed in the ordinary way ... and functioning as such within the legal system of the State." 61 So far as can be acertained from the report of the Dumbarton D.C. case the same is true of Tarmac Construction.

Where the Crown lets land to a tenant he would not normally be able to claim Crown immunity: Ministry of Agriculture, Fisheries and Food v. Fenkins. ${ }^{62}$ Even in the absence of an express statutory provision as in that case, it is difficult to see how a tenant could claim to be a Crown servant or in consimili casu to a Crown servant. But if the Crown required work to be undertaken for it - as in the Campbell A.G. (Arcam) $L t d$. case - and granted a lease to the firm undertaking the work for it, there seems no reason why the firm should not be entitled to Crown immunity. Support for this view can be derived from Nottingham Area No. 1 Hospital Management Committee v. Owen ${ }^{63}$ where the Divisional Court, in determining the scope of section 106 of the Public Health Act 1936 which referred to premises "occupied for the public service of the Crown", distinguished the purpose of the occupation from the status of the occupier. The question is occupation for Crown service or not; the title of the occupier is irrelevant. An unusual claim to invoke the immunity of the Crown from planning legislation was made in Spook Erection Ltd. v. Secretary of State for the Environment ${ }^{64}$ The appellant company, as the owner of a market franchise originating in a grant of Charles I, claimed to be entitled, like the Crown, to immunity from the Town and Country Planning Acts 1947 and 1971. The Court of Appeal held, however, that a franchise, once granted, is a private right. The holder is not acting in any sense on behalf of the Crown.

\section{The right of the Crown to take the benefit of a statute}

Section 31(1) of the Crown Proceedings Act 1947 provides that nothing in that Act shall "prejudice the right of the Crown to take advantage of the provisions of an Act of Parliament although not named therein." The existence of this right is attested to by Blackstone and Chitty. ${ }^{65}$ In Cayzer Irvine $\mathcal{E}$ Co. v. Board of Trade ${ }^{66}$ Scrutton LJ referred to the right but refrained from expressing any concluding view, while making typically trenchant comments on the alleged authorities cited in its support:

"a passage in an unsuccessful argument of a law officer which was not even relevant to the case before the Court, but which has been taken out by a text

61. At p.259, per Fullager J.

62. [1963] 2 Q.B. 317; cf. Retaruke Timbers Co. Ltd. v. Rodney C.C. [1984] 2 N.Z.L.R. 129.

63. $[1958]$ I Q.B. 50.

64. [1989] Q.B. 300.

65. Supra n.12; Hogg, supra n.10, p.180 et seq.; Craies, supra n.12, p.438, et seq.

66. [1927] 1 K.B. 269, 294. See also Nisbet Shipping Co. Lid. v. R. [1955] I W.L.R. 1031, 1035. 
writer and repeated for centuries until it was believed that it must have some foundation ${ }^{67} \ldots$ and possibly a passage in 7 Rep. $32 a,{ }^{68}$ which is not the report of a case decided in the House of Lords, but the case of a private conference between the law officers and the Chief Justices of the Stuart Kings in a case in which the parties, the subjects affected by the decision which was given against them, were not present and were not heard."

Sir Ivor Jennings commented that the case showed "upon what a slender basis of precedent rest some of the most familiar of our text book maxims." 69 Rather disappointingly in $\mathrm{ReCushla}{ }^{70}$ where the Crown sought the benefit of section 31 of the Bankruptcy Act 1914 Vinelott $J$ was able to find for the Crown on the construction of the section without having to resort to this rule.

\section{Criticism of the present law}

The presumption in favour of the immunity of the Crown as laid down in modern cases is wider than anything claimed by the old authorities. To show, in the absence of express words, that a statute binds by necessary implication it is necessary, according to the Privy Council in the Province of Bombay case, ${ }^{71}$ to demonstrate that otherwise the effect of the statute would be wholly frustrated. As Parliament increasingly legislates "for the public good" in the sense of laying down standards of public hygiene, conditions of employment, restrictions on pollution, it is difficult to see why the application of these standards to hospitals or prisons, for example, should depend on a rule of construction which itself depends on whether a particular activity - running a hospital - is a Crown service or not. The present position is clearly convenient for the executive. Legislation does not normally affect it unless by express provision - for example the Equal Pay Act 1970 , section 1(8). Were the rule of construction otherwise it would be necessary to seek and justify express exemption from legislation. As it is, the freedom of the executive is maintained until a particular case, such as Cooper v. Hawkins, ${ }^{72}$ exposes the absurdity of the Crown's immunity or political pressure finally secures the extension, for example, to hospital kitchens, of the legislation which for years has applied to commercial undertakings: National Health Service (Amendment) Act 1986.

67. Scrutton LJ is referring to remarks of counsel in the Magdalen College Case (1615) 11 Co. Rep.66b. 68. The Case of a Fine Levied by the King Tenant in Tail etc. (1605). This report considered whether the King "in his natural capacity as an Englishman, not in his public and royal capacity", could take advantage of De Donis to bar an entail. Coke thought he could: "it would be hard that the King ... should be in a worse condition than if he had not been King."

69. (1927) 43 L.Q.R. 157.

70. [1979] 3 All E.R. 415.

71. [1947] A.C. 58.

72. [1904] 2 K.B. 164. The result of the case was the Motor Car Act 1903, s. 16. The current provision, subjecting Crown servants to road traffic legislation, is section 183, Road Traffic Act 1988. 
If the Executive has no reason to wish to reverse the present presumption it is at least open to the courts to be more willing to find "the necessary implication" in the absence of express words. A reluctance to do so in the case of criminal liability is perhaps explicable and justifiable as the High Court of Australia suggested in Cain v. Doyle. ${ }^{73}$ But in reality there is nothing absurd in the Crown being prosecuted in its own courts in the twentieth century. Certainly no one would dispute that criminal liability can be expressly imposed on the Crown in the form of government departments or civil servants. In other areas, however, the courts could well adopt a more liberal approach. So far the only class of case where they have shown any willingness to construe statutes to the prejudice of the Crown is where a statute imposes conditions or restrictions on the exercise of a prerogative power: Attorney-General v. De Keyser's Royal Hotel; ${ }^{74}$ Manitoba Fisheries Ltd. v. The Queen. ${ }^{75}$ Both cases illustrate that even the deference shown to the Crown may give way to the respect of the common law for property rights.

The right of the Crown to claim the benefit of legislation not named in it has been little invoked in modern times. Its apparent unfairness, under which the Crown might invoke a statute in its favour while denying that it was bound by the same statute, would disappear if the presumption of construction in favour of the Crown were reversed. Until that time it will remain as one of the more curious consequences of the privileged position the Crown still holds in the common law.

A Scots lawyer might wish to end with a rather different criticism. Granted that the law on statutory interpretation should be the same in England and Scotland, as Lord Keith convincingly argued, could not that law be Scots law. At least might not its merits be examined before being abandoned. To some Lord Advocate v. Dumbarton D.C. ${ }^{76}$ might seem another example of the "pretentions of English law as 'imperial law'." 77

73. (1946) 72 C.L.R. 409. On this ground the decision in Cooper v. Hawkins [1904] 2 K.B. 164 can be defended.

74. [1920] A.C. 508; Hogg, supra n.10, 171.

75. [1978] 88 D.L.R. (3d) 462.

76. [1989] 3 W.L.R. 1346.

77. Sir Thomas B. Smith. Stair Memorial Encyclopaedia, vol. v, p.379. 